\title{
Grazing intensities and poultry litter fertilization levels on corn and black oat yield
}

\author{
Paulo Fernando Adami(1), Adelino Pelissari(1), Anibal de Moraes(1), Alcir José Modolo(2), \\ Tangriani Simioni Assmann (2), Marcia Fernanda Franchin ${ }^{(2)}$ and Luís César Cassol(2)
}

\begin{abstract}
(1)Universidade Federal do Paraná, Departamento de Fitossanidade, Rua dos Funcionários, № 1.540, Juvevê, CEP 80035-050 Curitiba, PR, Brazil. E-mail: paulo.adami@ifpr.edu.br, linopeli@hotmail.com, anibalm@ufpr.br (2)Universidade Tecnológica Federal do Paraná, Departamento de Agronomia, Via do Conhecimento, Km 1, CEP 85503-390 Pato Branco, PR, Brazil. E-mail: alcir@utfpr.edu.br, tangrisimioni@yahoo.com.br, marciafranc@hotmail.com,cassol@utfpr.edu.br
\end{abstract}

\begin{abstract}
The objective of this work was to assess the effect of poultry litter fertilization levels on corn and black oat yield using different grazing intensities, poultry litter levels (mixture of manure and bedding material) and a chemical fertilization level. The experimental design was a randomized complete block in a split-plot arrangement with four replicates. Black oat + ryegrass grazing intensities, characterized by different pasture sward management, with animal entrance at 25,30 and $35-\mathrm{cm}$ heights and exit at 5.0, 10 and $15-\mathrm{cm}$ heights, were established at the main plots. After the grazing period, corn was grown at the subplots with four levels of poultry litter $\left(0,4,953,9,907\right.$ and $\left.14,860 \mathrm{~kg} \mathrm{ha}^{-1}\right)$, aiming to supply $0,100,200$ and $300 \mathrm{~kg} \mathrm{ha}^{-1}$ of nitrogen, and a treatment with chemical fertilizer, according to soil analysis. Grazing intensities had no effect on corn yield. Corn yield was 7,493, 8,458,9,188, 10,247 and $11,028 \mathrm{~kg} \mathrm{ha}^{-1}$, respectively, for the treatments without and with 4,953, 9,907 and 14,860 $\mathrm{kg} \mathrm{ha}^{-1}$ of poultry litter, and the treatment with chemical fertilization. Poultry litter levels have a residual effect on the production of black oat grown in succession to corn.
\end{abstract}

Index terms: Avena strigosa, Zea mays, chemical fertilizer, organic fertilizer, residual effect, yield components.

\section{Intensidades de pastejo e níveis de adubação com cama de aviário sobre a produtividade de milho e aveia-preta}

\begin{abstract}
Resumo - O objetivo deste trabalho foi avaliar o efeito de níveis de adubação com cama de aviário sobre a produtividade de milho e aveia-preta com uso de diferentes intensidades de pastejo, níveis de cama de aviário (mistura de esterco e material utilizado como cama) e nível de adubação química. Utilizou-se o delineamento experimental de blocos ao acaso com parcelas subdivididas e quatro repetições. As intensidades de pastejo na aveia-preta + azevém, caracterizadas por diferentes alturas de manejo do pasto, com alturas de entrada dos animais em 25, 30 e $35 \mathrm{~cm}$ e de saída em 5,0,10 e $15 \mathrm{~cm}$, foram impostas nas parcelas principais. Após o período de pastejo, o milho foi cultivado nas subparcelas com quatro níveis de cama de aviário $(0,4.953,9.907$ e $14.860 \mathrm{~kg} \mathrm{ha}^{-1}$ ), para suprir $0,100,200$ e $300 \mathrm{~kg} \mathrm{ha}^{-1}$ de nitrogênio, e um tratamento com adubação química, conforme análise do solo. As intensidades de pastejo não afetaram a produtividade do milho. A produtividade do milho foi de $7.493,8.458,9.188,10.247$ e $11.028 \mathrm{~kg} \mathrm{ha}^{-1}$, respectivamente, para os tratamentos sem e com $4.953,9.907$ e $14.860 \mathrm{~kg} \mathrm{ha}^{-1}$ de cama de aviário e para o tratamento com adubação química. Há efeito residual dos níveis de cama de aviário na produtividade da aveia-preta cultivada em sucessão ao milho.
\end{abstract}

Termos para indexação: Avena strigosa, Zea mays, adubação química, adubação orgânica, efeito residual, componentes de produtividade.

\section{Introduction}

Corn is a major crop in Brazil, contributing with $30.9 \%$ of the country's grain production. Despite its importance in the maintenance of farms and agro-industry linked to poultry, swine and dairy cattle and of the continued evolution in productivity gains per area, the national average yield does not exceed 4 thousand $\mathrm{kg} \mathrm{ha}^{-1}$ (Companhia Nacional de Abastecimento, 2010) and is well below its potential. High-grazing intensity at crop-livestock areas and low fertilizer use may be cited among the reasons for the low corn yield per area.

Although there are many paradigms regarding the entrance of animals in crop lands, there is strong growth in integrated crop-livestock systems in Brazil (Moraes et al., 2002). The sustainability of the systems is directly related to grazing intensities, which affect pasture leaf area and canopy light interception and, consequently, the photosynthesis rate and the ability of plants to produce new leaves (Silva \& Pedreira, 1997).

Pesq. agropec. bras., Brasília, v.47, n.3, p.360-368, mar. 2012 
The physical-chemical and biological soil traits may also be affected, resulting in lower crop productivity when cultivated in sequence (Albuquerque et al., 2001). Therefore, the stocking rate used in the crop-livestock system determines both the agricultural and the livestock production (Carvalho et al., 2011). In this context, experiments with rotational grazing systems in order to evaluate different heights of sward management can contribute to the optimization of the production system.

In addition to grazing intensity, fertilization, especially with nitrogen, plays an important role in system productivity. According to Duete et al. (2008), nitrogen is the most required element by corn (Zea mays L.) and often the nutrient which most limits its yield. Moreover, one of the main difficulties faced by organic agriculture lies in nitrogen input to production systems.

Poultry litter stands out as an excellent organic fertilizer option due to its high concentrations of nitrogen, phosphorus and potassium (Preusch et al., 2002). Its use as an agricultural fertilizer also allows an environmentally friendly way of disposing of this waste, enhances soil physical, chemical and biological traits (Eghball et al., 2004; McGrath et al., 2009), and promotes an increase in soybean (Adeli et al., 2005), cotton (Mitchell \& Tu, 2005), corn (Konzen, 2003) and pasture yield (Sistani et al., 2004).

The current restrictions established by the Ministério da Agricultura, Pecuária e Abastecimento (Brasil, 2009) on the use of poultry litter on pastures have hampered and restricted its application, due to the difficulty in incorporating the litter, especially in areas of pasture implanted under no-tillage systems. Because of these restrictions, litter use in annual crops, such as corn, may be one of the best options for disposal and management of poultry litter (Klepker et al., 1989). However, research must be carried out in order to assess the effect of litter levels on corn yield. Furthermore, there are few reports in the literature on the efficiency of poultry litter compared with commercial fertilizer at similar rates. Another issue to take into account is the possible residual effect of poultry litter applied to summer crops over winter forage grass yield, which may allow lower applications of fertilizers with reduction in production costs.

Therefore, field experiments are needed to fully understand positive and negative impacts of livestock and poultry litter application on crop-livestock systems.

The objective of this work was to assess the effect of grazing intensities and poultry litter fertilizer levels on corn and black oat yield.

\section{Materials and Methods}

The experiment was done in 2009 and 2010 in a farm near Coronel Vivida, PR, Brazil, located in the third plateau physiographic region $\left(25^{\circ} 56^{\prime} \mathrm{S}\right.$ and $52^{\circ} 37^{\prime} \mathrm{W}$, at a $730-\mathrm{m}$ altitude). The climate of the region is subtropical humid, according to Köppen. The meteorological data of the experimental period are shown in Figure 1.

The experimental design was a randomized complete block in a split-plot arrangement. Main plots $\left(184 \mathrm{~m}^{2}\right)$ were represented by grazing intensities (sward height management), and subplots by poultry litter levels and chemical fertilizer, with four replicates. After corn harvest, residual effects of poultry litter were evaluated at the ungrazed plots and at the plots managed at $30 \times 10 \mathrm{~cm}$ of height (pasture height at the entrance and exit of animals from the paddocks, respectively) on the previous winter, using the same experimental design.

At the initial phase of the experiment, different grazing intensities on black oat (Avena strigosa Schreb.) plus ryegrass (Lolium multiflorum Lam.) were established in rotational grazing, considering different pasture sward heights: $25-5.0,30-10$ and $35-15 \mathrm{~cm}$, respectively, for the entrance and exit of animals

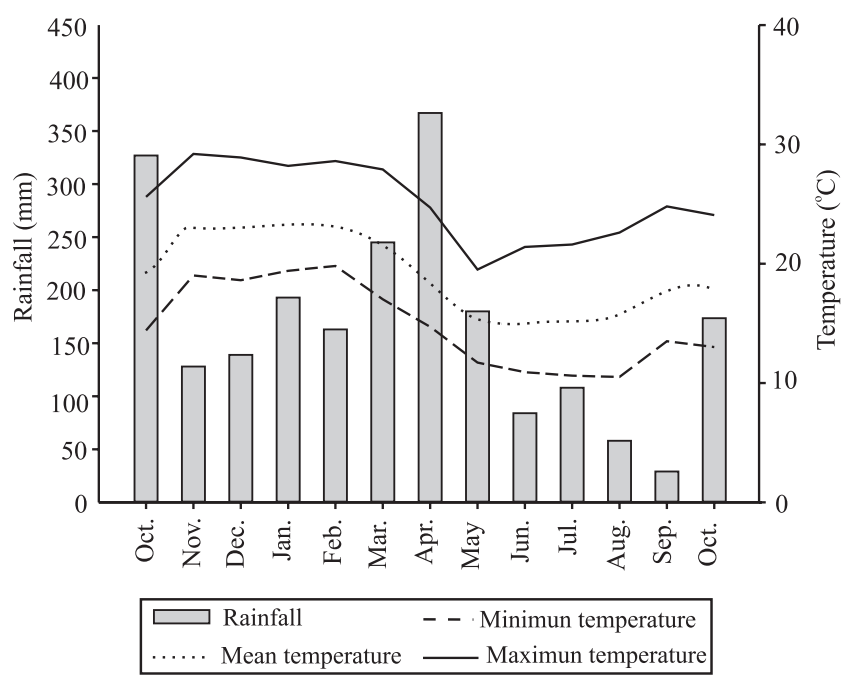

Figure 1. Meteorological data observed during the experimental period. 
from the paddocks, characterizing high, medium and low grazing intensities, with the addition of a control treatment without grazing. Dairy cows $(500 \mathrm{~kg}$ of live weight) were used in the experiment. In order to adjust the heights proposed, the animals were kept in the paddocks $\left(184 \mathrm{~m}^{2}\right)$ from 4 to 10 hours. After grazing, ungrazed sites were mowed to uniform pasture height according to the treatment.

After the grazing period (6/27/2009 to $9 / 16 / 2009)$, the area was desiccated (9/17/2009) with $740 \mathrm{~g} \mathrm{ha}^{-1}$ i.a. of glyphosate, and the main plots were divided into 80 subplots of $4.0 \times 3.0 \mathrm{~m}\left(12 \mathrm{~m}^{2}\right)$ with a $1.0-\mathrm{m}$ alley surrounding each plot, in which four levels of poultry litter $\left(0,4,953,9,907\right.$ and $\left.14,860 \mathrm{~kg} \mathrm{ha}^{-1}\right)$ and a chemical fertilizer treatment were established. The influence of grazing intensities and fertilizer levels on corn hibrid Pioneer 30R50 growth and yield was evaluated. Corn was sown on $10 / 14 / 2009$, with row spacing of $0.83 \mathrm{~m}$ and density of 60,000 plants per hectare, and was harvested on $3 / 6 / 2010$.

Poultry litter (mixture of manure and bedding material) was obtained from a broiler house with 11 flocks of birds produced in the same litter (average of 17 thousand birds per flock). Subsamples of poultry litter were collected for moisture and nutrient determination at the house cleaning period and just a few days before litter application on the field. Samples were dried at $55^{\circ} \mathrm{C}$ until constant weight.

After dry matter weight determination, litter biomass was ground in a Willey-type knife mill $(<40$ mesh) and sulfuric digestion was done with the total $\mathrm{N}$ determined by the Kjeldahl method (Tedesco, 1995). Using a subsample obtained in the digestion process, the total levels of $\mathrm{P}, \mathrm{K}$ and $\mathrm{Ca}$ were determined by spectrophotometry, flame spectrophotometry and atomic absorption spectrophotometry, respectively. Poultry litter dry matter content was $805 \mathrm{~g} \mathrm{~kg}^{-1}$, whereas nitrogen, phosphorous, potassium, calcium and magnesium contents were $25,17.6,37.2,44$ and $10.6 \mathrm{~g} \mathrm{~kg}^{-1}$, respectively.

Poultry litter levels were defined in order to supply $0,100,200$ and $300 \mathrm{~kg} \mathrm{ha}^{-1}$ of N. Based on poultry litter dry matter and $\mathrm{N}$ content, the amount of litter necessary to supply these amounts of $\mathrm{N}$ was calculated, yielding values of 4,953, 9,907 and $14,860 \mathrm{~kg} \mathrm{ha}^{-1}$ of poultry litter. In addition to $\mathrm{N}$, the above poultry litter levels also contained 136 and 178, 321 and 356, and 482 and
$534 \mathrm{~kg}$ of $\mathrm{P}_{2} \mathrm{O}_{5}$ and $\mathrm{K}_{2} \mathrm{O}$, respectively. Poultry litter was applied by hand at the corn sowing date (10/14/2009).

Chemical fertilization was done as recommended by the Sociedade Brasileira de Ciência do Solo (2004), for the expected corn production of 8.0 to $10 \mathrm{Mg} \mathrm{ha}^{-1}$, and according to the values found in soil analyses $(0$ to $15-\mathrm{cm}$ depth), which were: $\mathrm{pH}\left(\mathrm{CaCl}_{2}\right) 5.3 ; 9.93 \mathrm{mg} \mathrm{dm}{ }^{-3}$ of $\mathrm{P} ; 0.90 \mathrm{cmol}_{\mathrm{c}} \mathrm{dm}^{-3}$ of $\mathrm{K} ; 4.2 \%$ of organic matter; $6.2 \mathrm{cmol}_{\mathrm{c}} \mathrm{dm}^{-3}$ of $\mathrm{Ca}$; base saturation of $72 \%$; and CEC of $12.16 \%$. A total of $350 \mathrm{~kg} \mathrm{ha}^{-1}$ of the chemical formula N-P-K (09-33-12) was applied (31.5 kg ha-1 of N, $115.5 \mathrm{~kg} \mathrm{ha}^{-1}$ of $\mathrm{P}_{2} \mathrm{O}_{5}$ and $42 \mathrm{~kg} \mathrm{ha}^{-1}$ of $\mathrm{K}_{2} \mathrm{O}$ ) at planting time, and $150 \mathrm{~kg} \mathrm{ha}^{-1}$ of $\mathrm{N}$ were split-applied, one half at the plant four-to-six-leaves stage (11/11/2009) and the other half at plant 8-to-12-expanded-leaves stage (12/02/2009), according to Fancelli \& Dourado Neto (2000). Weather conditions and moisture levels were taken into account to make the best use of $\mathrm{N}$ by the system. The nitrogen source used was urea, with a concentration of $45 \%$ of $\mathrm{N}$.

Corn growth and yield components were evaluated during the corn cycle in order to assess the effects of grazing intensities and organic and inorganic fertilizer on corn yield. Plant heights were evaluated at 39, 50 and 86 days after corn sowing by measuring the distance from the ground to the insertion of the flag leaf of 14 plants per plot with a ruler graduated in centimeters. Stem diameter was evaluated 39 days after corn sowing by measuring the second internode of the stem from the soil surface. To determine corn yield components, 25 ears per plot were evaluated, and the length and thickness of the ear were measured with the aid of a digital caliper rule.

The number of grains per ear was determined by the ratio between the number of rows per ear and the number of kernels per row. The weight of a thousand grains was assessed by manual counting of 400 grains, weighing and correction of moisture content to $13 \%$, with extrapolation to a thousand-grain weight. To determinate corn yield, three central rows of the subplots were hand-harvested, threshed and weighed with a 1.0-g precision balance BG 2000, (Gehaka, São Paulo, SP, Brazil) at the soil lab of the Universidade Tecnológica do Paraná. Grain production per hectare was subsequently extrapolated, considering the standard of $13 \%$ moisture content.

The residual effect of poultry litter applied on corn was also evaluated regarding black oat yield. Black oat 
was sown in sequence over the grazed $(30 \times 10 \mathrm{~cm})$ and ungrazed plots in the previous winter, using the same experimental design. The evaluations were carried out by cutting two points $\left(0.25 \mathrm{~m}^{2}\right)$ at the soil level at each experimental unit every time black oat reached a $30-\mathrm{cm}$ height. The plots were then rubbed to a $10-\mathrm{cm}$ height. Samples were dried in a forced-air oven at $60^{\circ} \mathrm{C}$ until constant weight and weighed. Pasture production was periodically evaluated in order to better characterize the residual effect of poultry litter. Forage production of the first period considered the time elapsed from sowing (5/12/2010) to 7/12/2010 (62 days). The second cut considered the period from $7 / 13 / 2010$ to $8 / 27 / 2010$ (46 days), and the third from $8 / 28 / 2010$ to $10 / 8 / 2010$ (42 days), totaling an evaluation period of 150 days.

Experimental results were subjected to analysis of variance with the SAS software (SAS Institute, 2002). Means for the chemical fertilizer treatment were compared by the Tukey test, at 5\% probability, and regression analyses were applied to poultry litter levels.

\section{Results and Discussion}

There was no interaction between grazing intensities and poultry litter levels or differences among grazing intensities for any of the evaluated parameters in the treatments with poultry litter levels. Lopes et al. (2009) evaluated the effect of black oat + ryegrass managed at different heights $(12,19,28$ and $32 \mathrm{~cm})$, on a continuous stocking rate grazing system, on soybean development and reported no differences on soybean yield in relation to grazing intensities.

However, forage management at low heights and the lack of fertilization may not be able to maintain enough straw through time for the no-tillage system, resulting in unprotected soil subject to erosion and surface compaction, initiating the soil degradation process and the reduction of the crop-livestock system production (Carvalho et al., 2011).

This is easily observed in many crop-livestock farms, where possible negative effects of grazing occur because of errors, which are usually cumulative. The producer does not generally wait for a suitable plant height to bring the animals into the paddocks, and the animals start grazing before the complete establishment of the pasture. In association with the lack of fertilizer, this leads plants to an early impairment in the grazing season, which worsens with time through the repetitive entrance of animals into the paddocks with insufficient forage mass. All of these factors added together and repeated along time may affect soil parameters and result in lower productivity of the crop-livestock system.

Plant height and stem diameter measured during the corn production cycle differed among the poultry litter levels (Figure 2). Average corn growth rate for the first 86 days after sowing was $2.67,2.73,2.76$ and $2.79 \mathrm{~cm}$ per day, respectively, for the treatments without poultry litter, with $4,954,9,907$ and $14,860 \mathrm{~kg} \mathrm{ha}^{-1}$ of poultry litter. The major differences in growth rates were observed during initial corn development.

Corn plants of the treatment with $14,860 \mathrm{~kg} \mathrm{ha}^{-1}$ of poultry litter were $28 \mathrm{~cm}$ taller than the ones of the control, 50 days (12/2/2009) after corn sowing, although this difference diminished to $10 \mathrm{~cm}$ at 86 days after sowing (1/7/10). Mitchell \& Tu (2005), while evaluating the influence of poultry litter levels on cotton, found that plants treated with litter were taller. Besides plant height, a quadratic effect of the stem diameter in response to increasing poultry litter levels was also observed (Figure 2).

These differences may be explained by the decomposition dynamics of the litter, the total amount of $\mathrm{N}$ released to the soil and the possible limitation of nitrogen availability. According to Escosteguy et al. (1997), nitrogen determines the development of corn and enables significant increases in leaf area and dry matter production, resulting in higher grain yield.

There were differences in corn plant height and stem diameter regarding corn plant development in relation to the grazing intensities in the treatment with chemical fertilizer (Table 1). Corn development in the treatment without grazing and managed at $30 \times 10 \mathrm{~cm}$ was better than that of the treatment managed at $25 \times 5.0 \mathrm{~cm}$, although the difference observed was less than $12 \mathrm{~cm}$. The treatment with chemical fertilization also produced taller plants than those of the treatment with $14,860 \mathrm{~kg} \mathrm{ha}^{-1}$ of poultry litter. Mitchell \& Tu (2005), when comparing the same nitrogen level using ammonium nitrate and poultry litter, observed that cotton plants fertilized with chemical fertilizer showed higher height than the plants fertilized with poultry litter, results similar to those found in the present study.

According to Fancelli \& Dourado-Neto (2000), corn plants have their production potential defined since the initial development phase. These authors reported that, although the initial phase of corn development (up to 
three leaves) does not have a great capacity to absorb large quantities of $\mathrm{N}$, due to its small size, high levels of soil mineral $\mathrm{N}$ during this stage appear to be important in order to obtain high grain yields. Moreover, the authors stated that the number of rows and the number of grains per row of the corn ear are established before the appearance of the fourth leaf, when the production potential is defined.

Influence of poultry litter and chemical fertilizer on corn growth, as expressed by height and stem diameter (Figure 2 and Table 1) subsequently interfered with corn yield components and grain yield. All corn yield components showed a positive response with the use of poultry litter (Figure 3). Ear length and thickness size increased as the poultry litter level increased, showing a quadratic response. The same was observed for the number of rows per ear and the number of grains per row, which resulted in higher number of grains per ear as the litter levels increased. The weight of a thousand
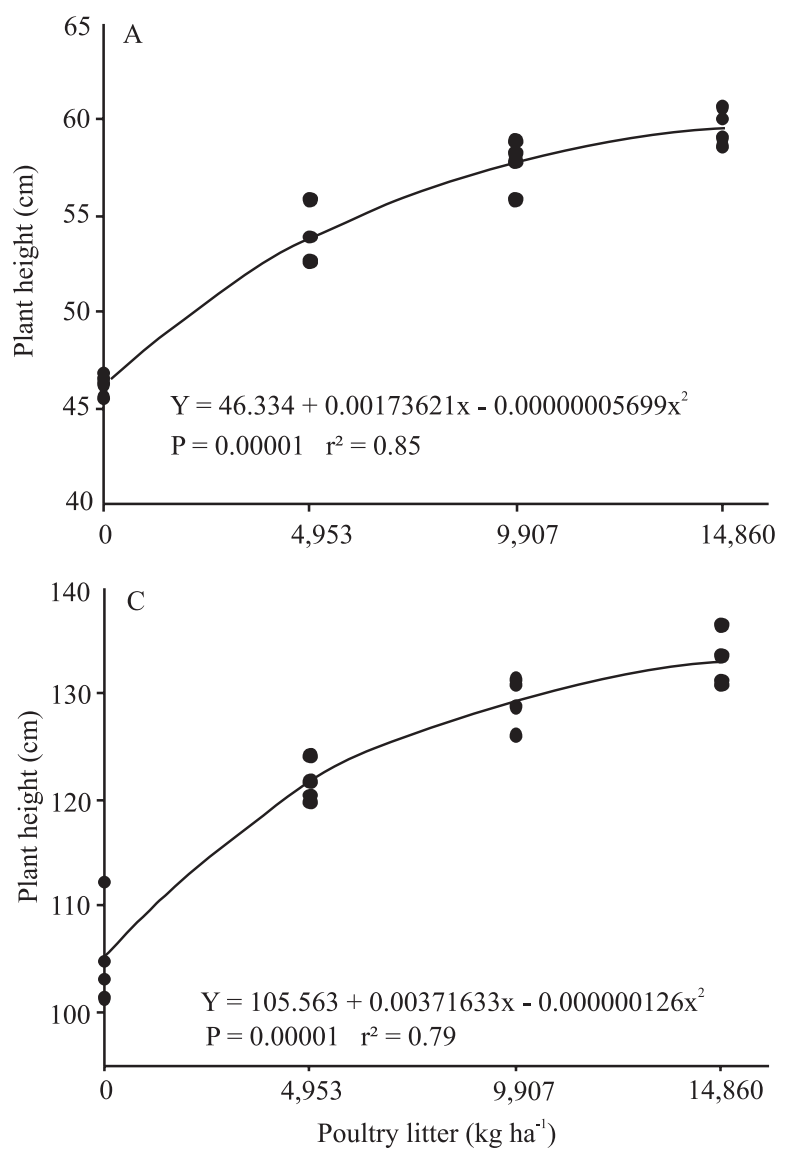

grains also increased as the poultry litter levels increased. Bortolini et al. (2001) have also reported a positive relation between yield components and corn production.

Among nutrients, $\mathrm{N}$ has the greatest effect on plant growth, and its availability stimulates root development and activity, increasing the absorption of $\mathrm{N}$ and of other nutrients (Yanai et al., 1996). To Duete et al. (2008), nitrogen is the nutrient required in largest amounts by the corn crop and, in many situations, the inadequate supply of $\mathrm{N}$ is considered a major factor limiting corn productivity.

The slight difference in the weight of a thousand grains between the $9,907 \mathrm{~kg} \mathrm{ha}^{-1}$ poultry litter treatment and the treatment with chemical fertilizer and the higher values of the $14,860 \mathrm{~kg} \mathrm{ha}^{-1}$ treatment may be explained by the litter decomposition dynamics. Since the weight of a thousand grains is determined during the latter corn development period, after the appearance of the tassel and the stigmas (Fancelli \& Dourado-Neto, 2000), and is influenced by the flow of photo-assimilates that
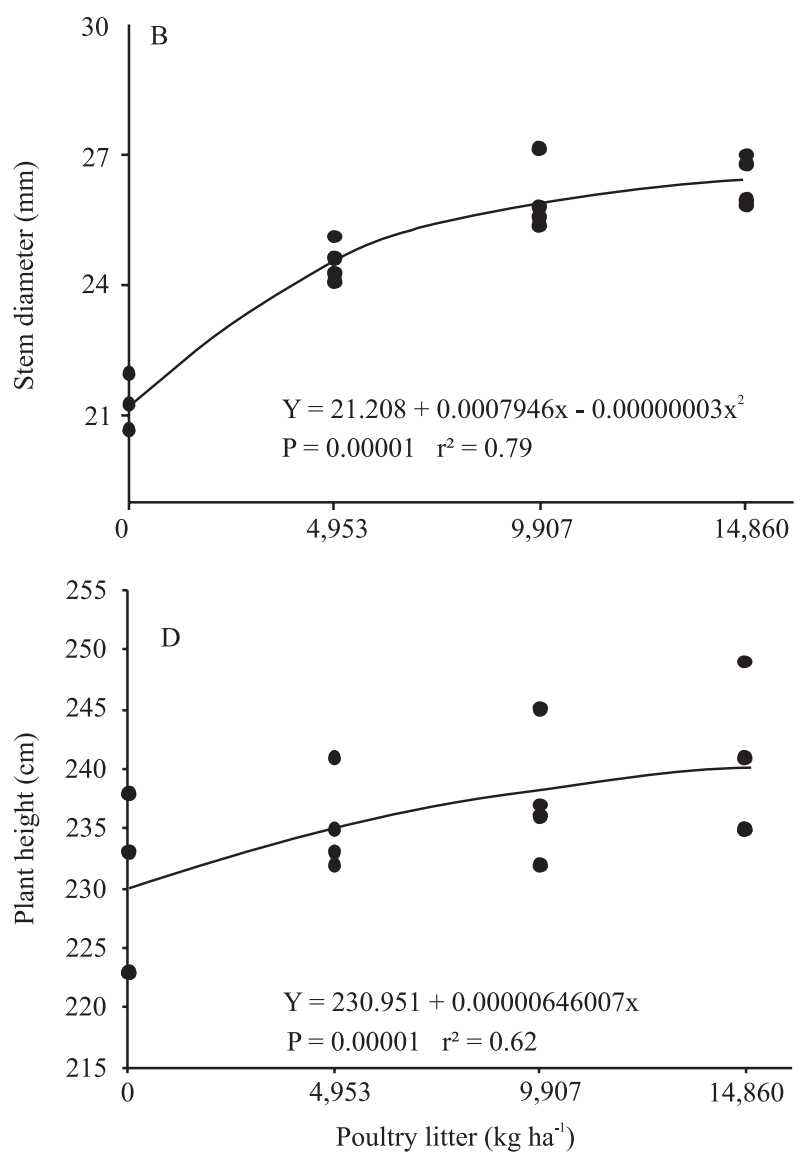

Figure 2. Corn plant height (A) and stem diameter (B) 39 days after sowing, and plant height at 50 (C) and 86 days (D) after corn sowing in relation to poultry litter levels. 
Table 1. Corn plant height $(\mathrm{cm})$ and stem diameter $(\mathrm{mm})$ in relation to the grazing intensities in the treatment with chemical fertilizer ${ }^{(1)}$.

\begin{tabular}{lccccc}
\hline Date & Parameter & Ungrazed & \multicolumn{3}{c}{ Grazing intensity } \\
\cline { 4 - 6 } & & & $35 \times 15$ & $30 \times 10$ & $25 \times 5.0$ \\
\hline $11 / 21 / 2009$ & Height & $64.16 \mathrm{a}$ & $60.57 \mathrm{~b}$ & $64.24 \mathrm{a}$ & $63.23 \mathrm{ab}$ \\
& Diameter & $27.58 \mathrm{a}$ & $26.82 \mathrm{ab}$ & $27.64 \mathrm{a}$ & $25.85 \mathrm{~b}$ \\
$12 / 2 / 2009$ & Height & $142.9 \mathrm{a}$ & $137.9 \mathrm{ab}$ & $142.1 \mathrm{a}$ & $134.5 \mathrm{~b}$ \\
$1 / 7 / 2010$ & Height & $246.0 \mathrm{a}$ & $238.0 \mathrm{bc}$ & $243.0 \mathrm{ab}$ & $234.0 \mathrm{c}$ \\
\hline
\end{tabular}

${ }^{(1)}$ Means followed by equal letters in the same row do not differ by Tukey test, at $5 \%$ probability.
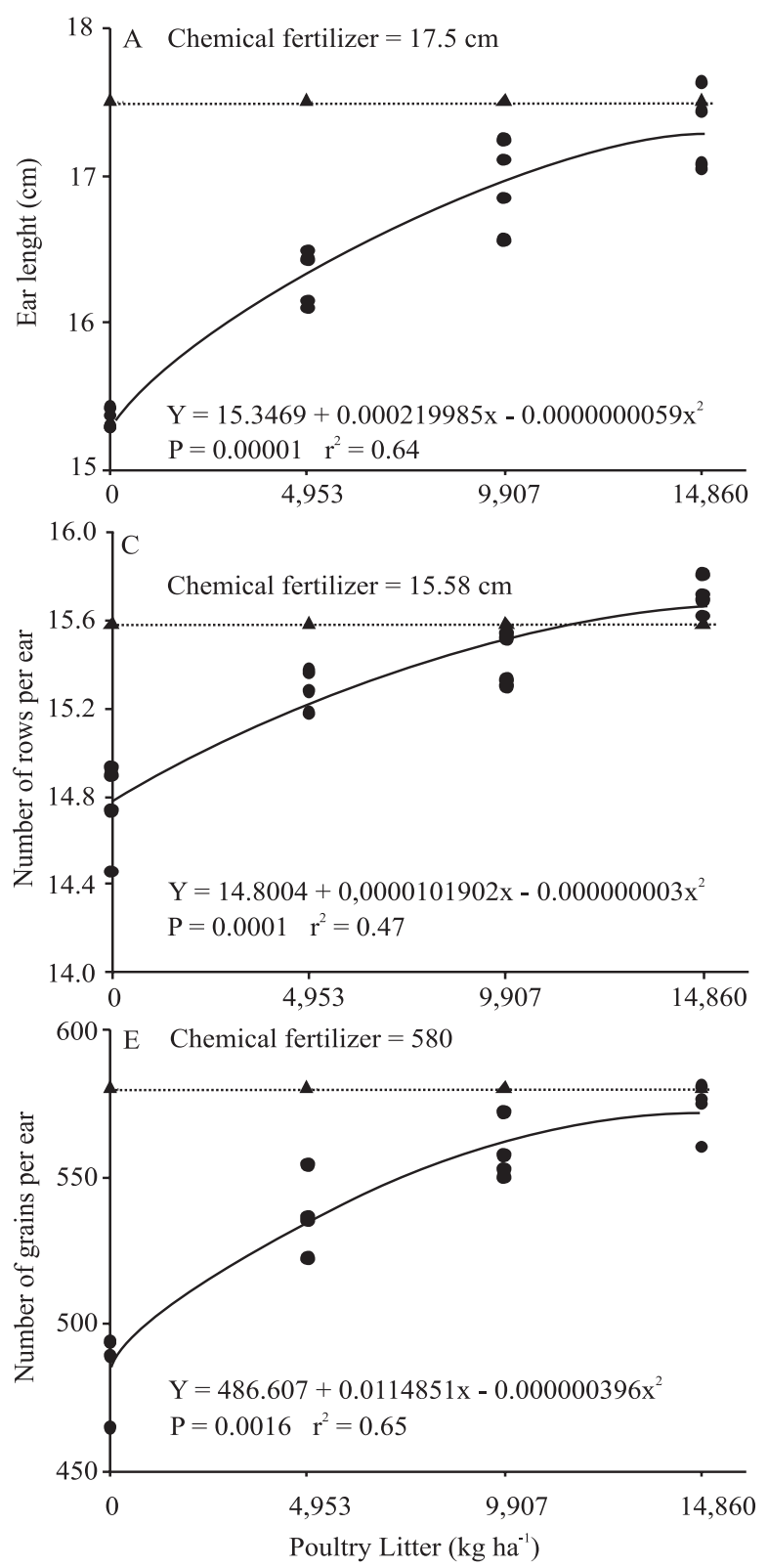

occurs during this period, it is possible to infer that, at this moment, higher amounts of $\mathrm{N}$ from the litter would be already available to the corn plants, allowing a higher weight of a thousand grains.

However, corn yield with different poultry litter levels was lower than with chemical fertilizer, as the number of grains per ear (defined by the number of rows and the number of grains per row), which is defined before the fourth leaf, was compromised, resulting in lower yields at the end of the corn cycle. This can be
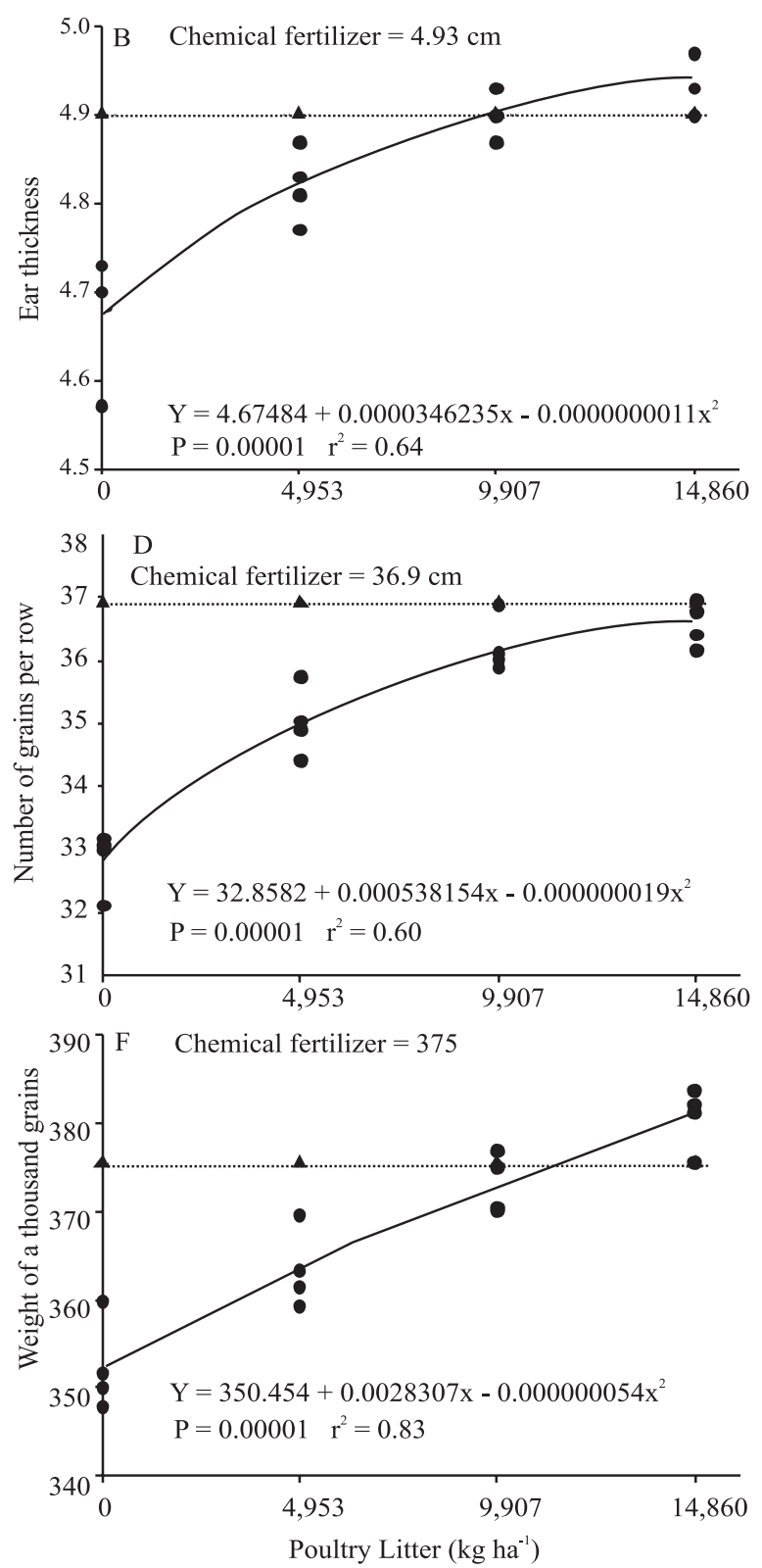

Figure 3. Corn yield components: ear length (A), ear thickness (B), number of rows per ear (C), number of grains per row (D), number of grains per ear (E) and weight of a thousand grains (F) in relation to poultry litter levels and chemical fertilizer. 
confirmed by the lower initial development of the corn plant, as evidenced by its height (Figure 2). According to Fancelli \& Dourado Neto (2000), when not limited by other factors, the increased availability of $\mathrm{N}$ increases the plant potential to produce a larger number of grains per ear and, consequently, higher yields.

Corn yield showed linear response to the poultry litter levels, as well as a residual effect on yield of black oat grown in sequence (Figure 4). Soil N and nutrients from animal waste, besides suitable climatic conditions for corn development associated with the application of $100 \mathrm{~kg} \mathrm{ha}^{-1}$ of $\mathrm{N}$ during the winter, may have influenced the response of the treatments, enabling high productivity of the control. Assmann et al. (2003), who evaluated the residual effect of nitrogen $\left(100 \mathrm{~kg} \mathrm{ha}^{-1}\right)$ applied during the winter on black oat over corn, found corn yield of $9,083 \mathrm{~kg} \mathrm{ha}^{-1}$.

Organic fertilization with 4,953, 9,907 and $14,860 \mathrm{~kg} \mathrm{ha}^{-1}$ of poultry litter increased corn grain yield in 12.8, 22.6 and $36.7 \%$ (965, 1,691 and $2,754 \mathrm{~kg} \mathrm{ha}^{-1}$ ) in comparison to the control. The highest grain yield obtained by the chemical fertilizer was $7.6 \%\left(778 \mathrm{~kg} \mathrm{ha}^{-1}\right)$, higher than the treatment with $14,860 \mathrm{~kg} \mathrm{ha}^{-1}$ of litter (Figure 4). Bortolini et al. (2001) reported corn yield of $9,470 \mathrm{~kg} \mathrm{ha}^{-1}$ with the application of $150 \mathrm{~kg} \mathrm{ha}^{-1}$ of $\mathrm{N}$.

Other studies have also reported the positive effect of poultry litter on crop productivity. Konzen (2003), assessing poultry litter levels of 3.6 and $5.0 \mathrm{Mg} \mathrm{ha}^{-1}$ on corn yield, observed values of 7,690 and $8,630 \mathrm{~kg} \mathrm{ha}^{-1}$, respectively, compared to the control, which produced

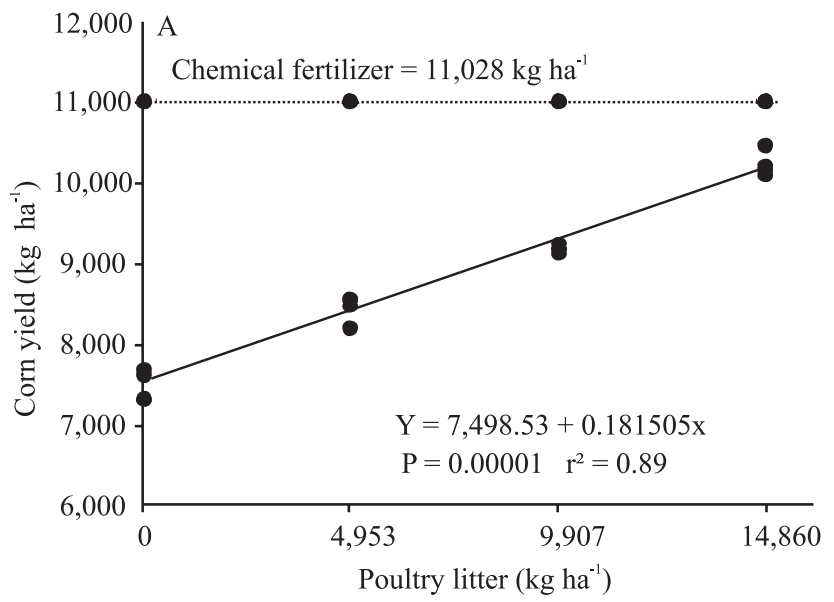

$6,690 \mathrm{~kg} \mathrm{ha}^{-1}$. Adeli et al. (2005) evaluated different levels of poultry litter on soybean development and reported a quadratic response in soybean yield. According to these authors, very high litter applications do not improve soybean yield and exceed the crop potential of nitrogen use, which is evidenced by the increased levels of nitrate in the soil. Sistani et al. (2004), while evaluating a forage grass ('Tifton 85') subjected to poultry litter levels, observed high dry matter production, which indicates that it is possible to get good pasture yields using only poultry litter.

Klepker et al. (1989) assessed the potential of poultry litter as a fertilizer on corn and found that the application of litter resulted in grain yields similar to those obtained with mineral fertilization recommended by the Sociedade Brasileira de Fertilidade do Solo (2004), for production expectations higher than $6.0 \mathrm{Mg} \mathrm{ha}^{-1}$. However, these authors also reported that the use of nitrogen (urea) significantly boosted yield. In this context, mixtures of litter and mineral $\mathrm{N}$ applied in sidedress at the initial phase of corn development seem to be a good strategy to obtain high corn yields.

Regarding the residual effect of poultry litter on yield of black oat cultivated after corn, there were differences between the levels of litter used and the grazing intensities (Figure 4). Black oat dry matter yield at plots subjected to the $30 \times 10-\mathrm{cm}$ grazing intensity during the previous winter was lower than that of the ungrazed treatment during the first period, with values of 1,873 and 2,003 $\mathrm{kg} \mathrm{ha}^{-1}$, respectively. During the second

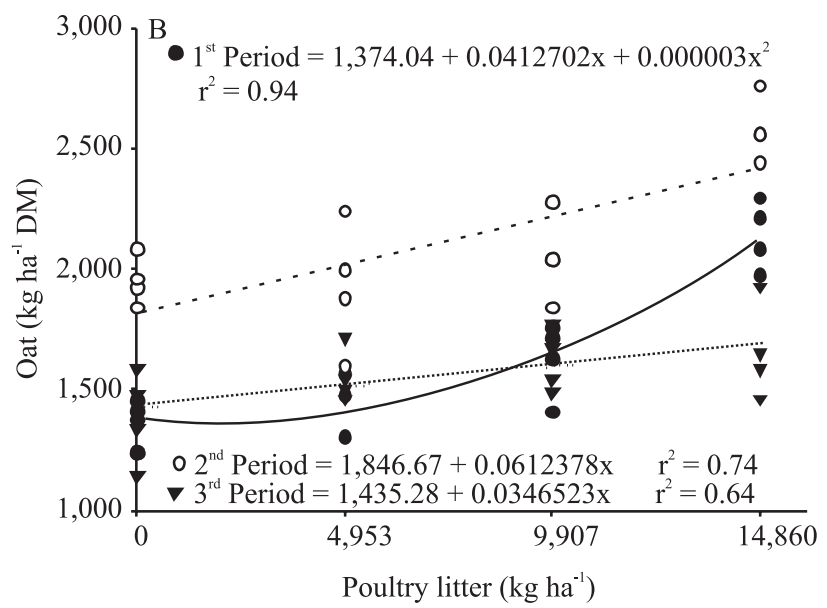

Figure 4. Corn production (A) in relation to poultry litter levels and chemical fertilizer, and black oat production (B) after corn crop in relation to poultry litter levels.

Pesq. agropec. bras., Brasília, v.47, n.3, p.360-368, mar. 2012 
and third periods, there were no differences between grazing intensities.

The greatest difference on black oat yield among poultry litter levels was observed during the first period of evaluation. Herbage production increased by 14.4, 53.3 and $88.8 \%$ as the poultry litter level increased, when compared to the control without litter. Mitchell $\& \mathrm{Tu}$ (2005) reported that the residual effect of poultry litter in the second year after its application resulted in cotton lint. These authors observed corn yield increases of $30 \%$ in relation to the treatment that received standard $\mathrm{N}$ fertilization rate during the prior year.

Reddy et al. (2009), when evaluating a cotton-cotton-corn rotation system with long-term poultry litter application, also observed residual effect on corn grain yield. Corn grown after cotton on residual poultry litter without fertilization showed higher grain yields (37 and 36\%) when compared to the cotton treatments that received ammonium nitrate at the same rate in 2005 and 2008, respectively. According to these authors, the surface application of poultry litter in no-tillage plots during cotton years may be responsible for its slow mineralization in the year of application and for the higher residual fertility in the following year. In addition to increased crop production, Eghball et al. (2004) reported that the residual effects of manure or compost application influenced soil properties for several years.

Nyakatawa et al. (2001) studied the residual effect of poultry litter and found that litter applied to cotton two years before corn was able to meet part of the $\mathrm{N}$ required by the corn crop. To Selbach \& Sá (2004), poultry litter residual effect can be observed in the third crop or 18 months after its application to perennial crops. According to these results, fertilizer application based on soil analysis should take into account litter residual effects, which, depending on their level, may possibly result in a reduction on the fertilizer application rates in the year after its use.

Regarding corn yield, the use of poultry litter instead of mineral fertilizer is probably not advantageous due to its high cost (average prices of 60 Reais per bag of fertilizer or urea or per ton of litter) and to the differences in corn yield of $1,840 \mathrm{~kg} \mathrm{ha}^{-1}$ between the mineral fertilizer and the litter level of $9,907 \mathrm{~kg} \mathrm{ha}^{-1}$. However, when the addition of nutrients to the soil from both fertilizer sources is considered, it is possible to infer that the organic fertilizer should be recommended since it is a source of more nutrients to the soil, with a difference between the $9,907 \mathrm{~kg} \mathrm{ha}^{-1}$ litter level and the mineral fertilizer of 19, 206 and $314 \mathrm{~kg} \mathrm{ha}^{-1}$ of N, $\mathrm{P}_{2} \mathrm{O}_{5}$ and $\mathrm{K}_{2} \mathrm{O}$, respectively.

Therefore, besides costs, it is also important to consider the benefits of nutrient addition to the soil, the release and residual effect dynamics (Nyakatawa et al., 2001; Mitchell \& Tu, 2005; Reddy et al., 2009), the effects on physical, chemical and biological soil traits (Eghball et al., 2004; McGrath et al., 2010) and the environmental impact of its usage, in order to make the best decision on which source to use.

According to Noce et al. (2010), poultry litter used as organic fertilizer provides positive results in the production of corn for silage and, depending on its cost and availability, it may replace chemical fertilization with advantages. Furthermore, the use of both sources together should be considered an important strategy to better balance the nutrients added to the soil, which may result in higher corn crop yield.

\section{Conclusions}

1. Grazing intensities do not affect corn yield components, such as ear length, ear thickness, number of rows per ear, number of grains per row, number of grains per ear and weight of a thousand grains, or corn grain yield.

2. Corn yield increases linearly as poultry litter fertilizer increases.

3. Poultry litter applied on corn crop has residual effect on dry matter production of black oat grown in succession.

\section{References}

ADELI, A.; SISTANI, K.R.; ROWE, D.E.; TEWOLDE, H. Effects of broiler litter on soybean production and soil nitrogen and phosphorus concentrations. Agronomy Journal, v.97, p.314-321, 2005.

ALBUQUERQUE, J.A.; SANGOI, L.; ENDER, E. Efeito da integração lavoura-pecuária nas propriedades físicas do solo e características da cultura do milho. Revista Brasileira de Ciência do Solo, v.25, p.717-723, 2001.

ASSMANN, T.S.; RONZELLI JÚNIOR, P.; MORAES, A.; ASSMANN, A.L.; KOEHLER, H.S.; SANDINI, I. Rendimento de milho em área de integração lavoura-pecuária sob o sistema plantio direto, em presença e ausência de trevo branco, pastejo e nitrogênio. Revista Brasileira de Ciência do Solo, v.27, p.675-683, 2003.

BORTOLINI, C.G.; SILVA, P.R.F. da; ARGENTA, G.; FORSTHOFER, E.L. Rendimento de grãos de milho cultivado após 
aveia-preta em resposta a adubação nitrogenada e regime hídrico. Pesquisa Agropecuária Brasileira, v.36, p.1101-1106, 2001.

BRASIL. Ministério da Agricultura, Pecuária e Abastecimento.

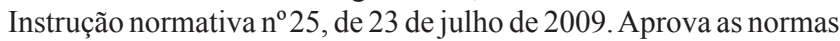
sobre as especificações e as garantias, as tolerâncias, o registro, a embalagem e a rotulagem dos fertilizantes orgânicos simples, mistos, compostos, organominerais e biofertilizantes destinados à agricultura. Diário Oficial [da] República Federativa do Brasil, 28 jul. 2009. Seção 1, p.18.

CARVALHO, P.C. de F.; ANGHINONI, I.; KUNRATH, T.R.; MARTINS, A.P.; COSTA, S.E.V.G. de A.; SILVA, F.D.; ASSMANN, J.M.; LOPES, M.L.T.; PFEIFER, F.M.; CONTE, O.; SOUZA, E.D. Integração soja-bovinos de corte no sul do Brasil. Porto Alegre: Universidade Federal do Rio Grande do Sul, 2011. $62 \mathrm{p}$.

COMPANHIA NACIONAL DE ABASTECIMENTO. Acompanhamento da safra brasileira, quarto levantamento, janeiro 2010. Brasília: Conab, 2010. 39p.

DUETE, R.R.C.; MURAOKA, T.; SILVA, E.C. da; TRIVELIN, P.C.O.; AMBROSANO. E.J. Manejo da adubação nitrogenada e utilização do nitrogênio $\left({ }^{15} \mathrm{n}\right)$ pelo milho em Latossolo Vermelho. Revista Brasileira de Ciência do Solo, v.32, p.161-171, 2008.

EGHBALL, B.; GINTING, D.; GILLEY, J.E. Residual effects of manure and compost applications on corn production and soil properties. Agronomy Journal, v.96, p.442-447, 2004.

ESCOSTEGUY, P.A.V.; RIZZARDI, M.A.; ARGENTA, G. Doses e épocas de aplicação de nitrogênio em cobertura na cultura do milho em duas épocas de semeadura. Revista Brasileira de Ciência do Solo, v.21, p.71-77, 1997.

FANCELli, A.L.; DOURADO-NETO, D. Produção de milho. Guaíba: Agropecuária, 2000. 360p.

KLEPKER, D.; CERETTA, C.A.; BAYER, C. Efeito da cama de aviário, nitrogênio em cobertura e calagem sobre o rendimento de grãos de milho (Zea mays L.). Revista Centro de Ciências Rurais, v.19, p.203-210, 1989.

KONZEN, E.A. Fertilização de lavoura e pastagem com dejetos de suínos e cama de aves. Sete Lagoas: Embrapa Milho e Sorgo, 2003. 16p. (Embrapa Milho e Sorgo. Circular técnica, 31).

LOPES, M.L.T.; CARVALHO, P.C. de F.; ANGHINONI, I.; SANTOS, D.T. dos; AGUINAGA, A.A.Q.; FLORES, J.P.C.; MORAES, A. de. Sistema de integração lavoura-pecuária: efeito do manejo da altura em pastagem de aveia preta e azevém anual sobre o rendimento da cultura da soja. Ciência Rural, v.39, p.1499-1506. 2009.

MCGRATH, S.; MAGUIRE, R.O.; TACY, B.F.; KIKE, J.H. Improving soil nutrition with poultry litter application in low input forage systems. Agronomy Journal, v.102, p.48-54, 2010.

MITCHELL, C.C.; TU, S. Long-term evaluation of poultry litter as a source of nitrogen for cotton and corn. Agronomy Journal, v.97, p.399-407, 2005.
MORAES, A.; PELISSARI, A.; ALVES, S.J.; CARVALHO, P.C.F.; CASSOL, L.C. Integração lavoura-pecuária no Sul do Brasil. In: ENCONTRO DE INTEGRAÇÃO LAVOURA-PECUÁRIA NO SUL DO BRASIL, 1., 2002, Pato Branco. Anais. Pato Branco: CEFET-PR, 2002. p.3-42.

NOCE, M.A.; CARVALHO, D. de O.; OLIVEIRA, A.C. de; CHAVES, F.F. Fertilização orgânica do milho para silagem utilizando cama de frango em doses e sistemas de aplicação distintos. In: CONGRESSO NACIONAL DE MILHO E SORGO, 28.; SIMPÓSIO BRASILEIRO SOBRE A LAGARTA DO CARTUCHO, 4., 2010, Goiânia. Anais. Goiânia: Associação Brasileira de Milho e Sorgo. 2010. p.2530-2535.

NYAKATAWA, E.Z.; REDDY, K.C.; BROWN, G.F. Residual effect of poultry litter applied to cotton in conservation tillage systems on succeeding rye and corn. Field Crops Research, v.71, p.159-171, 2001

PREUSCH, P.L.; ADLER, P.R.; SIKORA, L.J.; TWORKOSKI, T.J. Nitrogen and phosphorus availability in composted and uncomposted poultry litter. Journal of Environmental Quality, v.31, p.2051-2057, 2002.

REDDY, S.S.; NYAKATAWA, E.Z.; REDDY, K.C.; RAPER, R.L.; REEVES, D.W.; LEMUNYON, J.L. Long-term effects of poultry litter and conservation tillage on crop yields and soil phosphorus in cotton-cotton-corn rotation. Field Crops Research, v.114, p.311-319, 2009.

SAS INSTITUTE. SAS: user's guide: statistics. Version 8.2. 6.ed. Cary: SAS Institute, 2002.

SELBACH,P.A.; SÁ, E.L.S.Fertilizantes orgânicos, organominerais e agricultura orgânica. In: BISSANI, C.A.; GIANELLO, C.; TEDESCO, M.J.; CAMARGO, F.A.O. (Ed.). Fertilidade dos solos e manejo da adubação de culturas. Porto Alegre: Gênesis, 2004. p.328.

SILVA, S.C.; PEDREIRA, C.G.S. Princípios da ecologia aplicados ao manejo de pastagem. In: SIMPÓSIO SOBRE ECOSSISTEMA PASTAGEM, 3.,1997, Jaboticabal. Anais. Jaboticabal: FUNEP, 1997. p.1-62.

SISTANI, K.R.; BRINK, G.E.; ADELI, A.; TEWOLDE, H.; ROWE, D.E. Year-round soil nutrient dynamics from broiler litter application to three bermudagrass cultivars. Agronomy Journal, v.96, p.525-530, 2004.

SOCIEDADE BRASILEIRA DE CIÊNCIA DO SOLO. Comissão de Química e Fertilidade do Solo. Manual de adubação e calagem para os Estados do Rio Grande do Sul e de Santa Catarina. 10.ed. Porto Alegre: Sociedade Brasileira de Ciência do Solo, 2004. 394p.

TEDESCO, M.J. Análise de solo, plantas e outros materiais. Porto Alegre: UFRGS, 1995. 174p.

YANAI, J.; LINEHAN, D.J.; ROBINSON, D.; YOUNG, I.M.; HACKETT, C.A.; KYUMA, K.; KOSAKI, T. Effects of inorganic nitrogen application on the dynamics of the soil solution composition in the root zone of maize. Plant and Soil, v.180, p.1-9, 1996.

$\overline{\text { Received on April 5, } 2011 \text { and accepted on January 31, } 2012}$ 